\title{
Composition And Diversity Of Plant Species In The Two Types Of Land Cover Of Natural Laboratory Of Hampangen Educational Forest
}

\author{
Sosilawaty ${ }^{1}$, Belinda Hastari ${ }^{2}$, Ricardo Siregar ${ }^{3}$ \\ ${ }^{1,2,3}$ Faculty of Agriculture, Palangka Raya University, Indonesia \\ *Corresponding author: sosilawaty@for.upr.ac.id
}

Received: November 11, 2020. Revised: March 23, 2021. Accepted: April 10, 2021. Published: May 14, 2021.

\begin{abstract}
Forests are natural resources that contribute to sustaining life support systems. The purpose of this study was to determine the composition and diversity of plant species in the Hampangen Educational Forest Nature Laboratory with the object of research on plant species diversity at growth rates of seedlings, poles, saplings, and trees in the observation plots of secondary swamp forest and swamp scrub. The research was conducted using a combination technique of paths and checkered lines in each of the 30 measurement plots in the two types of observation land. The results showed 52 types of plants found in all types of research land-a total of 42 species in secondary swamp forest and 26 species in scrublands. The types of plants that occupy the highest IVI at all growth levels are Akasia, Jambu-jambu, and Meranti. The Diversity Index of plant species in the study area on both land types was classified as moderate, namely in the range $1,871-2,968$. The evenness index value $(E)$ of plants in the land cover type of secondary swamp forest and swamp scrub was classified as high in the range of $0.753-0.849$. The Species Richness Index $(R)$ value of the secondary swamp forest land cover type is classified as high, whereas the swamp scrub land cover type is classified as low, while the average species similarity index in the two land cover types is low.
\end{abstract}

Keywords: composition study, diversity index, land cover type

\section{INTRODUCTION}

The Hampangen Educational Forest Nature Laboratory area is one of the protected areas and is legally designated as an educational forest and has an area of 5,000 hectares. The Hampangen Educational Forest Nature Laboratory area is one of the conservation areas in Central Kalimantan Province, which plays an essential role in protecting and preserving the forest ecosystem and preserving living natural resources. However, this area is experiencing problems that cause the area to be threatened. Illegal logging is one of the problems that has occurred in this region. Illegal logging can cause changes in the composition and diversity of vegetation species and their results of succession [1]-[4]. Another thing that affects is the lack of community knowledge on boundary demarcation, leading to land-use conflicts against the community. Activities such as forest encroachment and free public access to the area, forest fires will more or less cause significant changes to the ecosystem in the area of the Hampangen Educational Forest Nature Laboratory.

The initial indicator to describe the conditions and phenomena in which a plant species grows is the change in the composition and diversity of peat swamp forest plant species. In land units, if there is good diversity and composition of swamp forest plant species, then the land has a stable condition. Conversely, if the diversity and composition of forest stands are damaged, the ecosystem condition is less stable. Peat forest areas where the ecosystem experiences deforestation and degradation have a significant impact on the surrounding environmental conditions and is prone to land fires in the dry season [5]-[10]. The disturbance on the peat swamp forest ecosystem is a factor that causes changes to the diversity of plant species and the composition that grows in them.

Continuous assessment on the condition of swamp ecosystems, especially on the diversity of species and composition of forest stands, is carried out to determine the function of the swamp forest structure and the composition of plant species in maintaining the stability of the overall ecosystem. Studying the diversity of species and composition of plants contained in the Hampangen Educational Forest Nature Laboratory area is one of the steps to get a good knowledge of the basic ecology needed in the development of a sustainable forest management scheme.

This study aims to calculate and analyze the composition and diversity of plant species in the Hampangen Educational Forest Nature Laboratory area. 


\section{MATERIAL AND METHOD}

The research was carried out in the area of the Natural Laboratory of Educational Forest of Hampangen, Palangka Raya University, Central Kalimantan Province, with the object of research on plant species diversity at growth rates of seedlings, poles, saplings, and trees in the observation plots of secondary swamp forest and swamp scrub. The process of collecting field data is carried out using a combination technique between paths and checkered lines so that tree measurements are carried out by the path method. At the same time, the regeneration rate (poles, stakes, seedlings) is measured by the checkered line method [11]. The line of observation was determined by purposive sampling, which is based on the type of forest consisting of secondary swamp forest and swamp scrub. Each forest type is made of 2 (two) observation paths that are placed in a systematic sampling manner with a length of $300 \mathrm{~m}$, a width of $20 \mathrm{~m}$, and a distance between $100 \mathrm{~m}$ so that the total area of observation paths in secondary swamp forest and shrubs is $1200 \mathrm{~m}^{2}$ each $(1,2$ ha). In the line of observation, a measuring plot measuring $20 \times 20 \mathrm{~m}$ is made so that each forest type will have 30 measuring plots.

Measurements were made for 4 (four) growth levels, namely, the seedling level on the subplot (a) measuring $2 \times 2$ $\mathrm{m}$, the state level in the subplot (b) measuring $5 \times 5 \mathrm{~m}$, the pile level in the subplot (c) measuring $10 \times 10 \mathrm{~m}$, and the tree level in the subplot (d) measuring $20 \times 20 \mathrm{~m}$. Measurement data collected for seedlings and saplings were in the form of number and species of plants, while for poles and trees, the data collected were in the form of number, species, diameter, and height of stands.

\section{Data analysis}

The analysis is carried out by calculating the parameters, which include:

1. Importance Value Index (IVI)

Importance value index (IVI) is a quantitative

parameter that can be used to express the level of dominance (level of control) of species in a plant community [12], [13]. The index of importance is obtained from the sum of Relative Density, Relative Frequency, and relative basal area (Relative dominance) (LAB / DR), where:

$$
\mathrm{INP}=\mathrm{KR}+\mathrm{FR}+\mathrm{DR}
$$

2. Species Diversity Index (H")

$$
H^{\prime}=-\sum_{i=1}^{s}(p i)(\ln p i)
$$

Information :

$$
\begin{array}{lll}
\mathrm{H}^{\prime} & = & \text { Species diversity index Shanon - Weiner } \\
\mathrm{Pi} & = & \text { The number of individuals of the nth type } \\
\mathrm{N} & = & \text { Total number of individuals }
\end{array}
$$

The magnitude of the species diversity index, according to Shannon-Wiener, is as follows:

a. Value $\mathrm{H}^{\prime}>3$ shows that the diversity of species is abundant (high) with a high number of individual wealth. b. Value $H$ 'between 1 and $3\left(1=\mathrm{H}^{\prime}=3\right)$ indicates that species diversity is moderate.

c. Value $H^{\prime}=1$ indicates that the diversity of species is low or low.

\section{Species Evenness Index (E)}

$$
E=\frac{H^{\prime}}{\ln S}
$$

Information:

$\mathrm{E}=$ Uniformity Index (between 0-1)

$\mathrm{H}^{\prime}=$ Shannon-Weiner Diversity Index

$\mathrm{s}=$ Number of tree species

4. Species Richness Index (R)

$$
\text { Margalef's Indeks: } \mathrm{D}_{\mathrm{mg}}=(\mathrm{S}-1) / \mathrm{ln} \mathrm{N}
$$

Information :

Dm $=$ Margalef Species Richness Index

$\mathrm{S}=$ number of species observed

$\mathrm{N}=$ total number of individuals of all species in the sample,

$\ln =$ Natural logarithm.

Margalef's species wealth index $\left(\mathrm{R}^{\prime}\right)$ criteria are:

a. $\mathrm{R}<3.5=$ low specificity

b. $3.5<\mathrm{R}<5.0=$ medium density

c. $\mathrm{R}>5.0=$ high density.

5. Species Similarity Index (SI)

$$
C s=\frac{2 c}{(a+b)} \times 100 \%
$$

Information :

$\mathrm{Cs}=$ Sorenson Similarity Index

$\mathrm{a}=$ Number of species in sample A.

$\mathrm{b}=$ Number of species in sample B.

$\mathrm{c}=$ The number of samples that are the same in both samples If the SI value is $>50 \%$, then the area has the same species in the community. If the IS value is $<50 \%$, then in that area, there are differences in the types of community constituents or do not even have the same type.

\section{RESULTS AND DISCUSSION}

\section{A. Composition and Dominance of Species}

The results of plant analysis found in the research location on secondary swamp forest land and swamp scrub contained 52 species of plants. Most of these species are found in secondary swamp forests, namely 46 species, while those found in swamp scrub are 26 species. The dominant species found in secondary swamp forests among others Jambu-jambu, Mahang, Nyatoh Meranti, Gerunggang, while in swamp shrubs among others, Acacia, Tumih, Tutup kabali, Jambu-jambu and Gerunggang. The number of plant species at the research location is shown in Figure 2.

Based on the results of research on the cover type of secondary swamp forest as well as swamp scrub, the composition was dominated by the species of pole-level plants. This is thought to be due to illegal logging and sand mining which resulted in land clearing. In addition, fewer plant species at all growth levels were found in the swamp scrub land cover type because the land cover was burnt.[14] 
explained in his research at the Hampangen Educational Forest Nature Laboratory, where burnt land conditions provided nutrient dynamics that affected the growth of plant species, both pioneer and non-pioneer species. Furthermore, he explained that there are still many shrubs found at the research location, which can inhibit the growth rate of a plant species.

Importance Value Index (IVI) is used as a quantitative parameter that can express the level of dominance (level of control) of species in a community. The plant species that have the highest IVI are due to their higher density, frequency, and dominance than other types. The higher the IVI of a species, the higher the level of control in the community of that species grows. The dominant species is the species that can make more efficient use of the occupied environment than other species within the same place. The presence of a plant species in an area shows the ability to adapt to a wide habitat and tolerance to environmental conditions. The greater the IVI value of a species, the greater the level of control over the community and vice versa [15], 1994). Control of certain species in a community if the species concerned manages to place a large proportion of the available resources compared to other species [16]. The dominance of the species found at the research location can be seen from the IVI size for the level of seedlings, saplings, poles, and trees [17]. The highest IVI in secondary swamp forest and swamp scrub can be seen in Table 1.

Based on Table 1, the dominant plants at the seedling level for secondary swamp forest cover type are Jambu-jambu, shown by an IVI value of $33,874 \%$. The dominating plant in swamp scrub is acacia, with an IVI value of $63,369 \%$. Acacia is an exotic species and is not the original species of peat swamp forest. The presence of this species was thought to have been initially planted by the community around the research location or influenced by vectorial factors (external environmental influences) such as the spread of seeds carried by the climate or allowed to live, which gave individual growth faster and was more dominant. Acacia and jambujambu are invasive plants that can produce rapidly or proliferate (fast-growing species), with high seed dispersal ability, usually through wind and tolerance of various circumstances in which to grow. According to [18], the presence of invasive foreign plants can interfere with natural habitats and threaten the existence of native plant species. However, the results of research conducted in the Bukit Soeharto Research and Education Forest area [19] prove that A. mangium is not a genuinely invasive type and is recommended as a critical land control plant as long as the potential threat of forest fires can be prevented.

The sapling level also shows the same thing as the growth level of seedlings, where the dominant plant species in the secondary swamp forest land cover type is Jambu-jambu, while the species that dominates the swamp scrub is acacia. The dominant plants at the sapling level are influenced by the density and frequency of one species, which is more than other species. Plant species with the highest IVI to the lowest at sapling growth level show the order of species adjustment in growth competition in the land cover type of secondary swamp forest. In contrast, the type of scrubland cover is highly dependent on other characteristics during the overall growth. According to [20], in general, plants with the highest IVI have better adaptation, competence, and reproductive capacity than other plants in a specific area.

Based on Table 1, we can see that the plants at the pole level that dominate the cover type of secondary swamp forest and swamp scrub are Meranti and Acacia plants. This shows that the meranti species, besides having the dominant plant species, also have a good level of compatibility with other commercial species and can maintain their existence. Meranti is found mainly in kerangas forest and seasonal swamp forest, and in peat swamp forest according to [21]. The dominant species at the pole level is influenced by the density, frequency, and dominance of one species compared to other plant species. Based on the value of the importance index, the three species can be said to be the species that have the most role and can utilize the environment efficiently compared to other plant species. Thus, the existence of the three dominant species is significant and is likely to become a species that can improve the composition of plants in the next generation of forests. According to [22], a species is dominant if the species concerned is present in large numbers in an area.

Meranti is a plant species with the highest IVI in secondary swamp forest areas, while in swamp scrub forest areas, the highest IVI is Acacia. Tree growth level plants are the types that have the least amount of each growth level, starting from seedlings, saplings, and poles. This is presumably because the land conditions in secondary swamp forest and swamp scrub in this study area are former HPH areas that later become secondary forest and are still in the process of succession. The tree growth level is less than the growth level of poles.

Based on the analysis of plant species and field findings, data on each growth level was dominated by Jambu-jambu species. This is thought to be influenced by the history of the Hampangen Educational Forest Nature Laboratory area, which is a degraded land that has developed a fairly mature and balanced ecosystem. The development of this ecosystem gave rise to several plant communities dominated by pioneer plants such as Jambu-jambu. According to [23], jambu-jambu is a type of pioneer because it grows faster than other plants and can withstand several conditions or natural factors, likes light, so it is easy to grow on burned and open land.

The results of IVI analysis of each type in the growth rate/level have varying values. IVI is one of the quantitative parameters used to express the level of dominance (level of control) of species in a plant community. Dominant (ruling) species in a plant community will have the highest IVI value, so the most dominant species certainly has the most excellent IVI [24]-[26]

\section{B. Species Diversity Index ( $\left.H^{\prime}\right)$}

Species diversity is a community-level characteristic based on its biological organization. Species diversity can be used to express community structure [27]-[29]. Species diversity states a measure that describes the variety of plant species from a community which is influenced by the number of species and the relative abundance of each species. The existence of species in a community from year to year can be 
measured from the species diversity index $\left(\mathrm{H}^{\prime}\right)$. The diversity index value can be seen in Figure 3.

The diversity index value $\left(\mathrm{H}^{\prime}\right)$ refers to the Weiner Shannon diversity index criteria on both land cover types, namely secondary swamp forest and swamp scrub for seedlings, saplings, poles, and trees, which are included in the medium criteria. Variation in the species diversity index $\left(\mathrm{H}^{\prime}\right)$ as in Figure 3 shows that the land cover type of secondary swamp forest has a higher value than the type of swamp scrub land cover. The study results found that the number of species in secondary swamp forest type was higher than in swamp scrub forest type The highest and most abundant diversity index is found in secondary swamp forest land cover (Figure $3)$. This is because in the secondary swamp forest land cover class, the vegetation in it is still intact, although the logging on species is considered commercial. In the swamp scrub forest type, fires had occurred, which caused the diversity of existing stands species to become extinct. This condition causes the succession to take place very slowly. [30] stated that if a severe fire occurs in a peat swamp forest, it is unlikely that the vegetation structure will return to its original state, furthermore, according to [31]-[33].

Forest resources that have undergone many changes will be very susceptible to damage so that in areas that have been burned, there will be many empty areas with the main vegetation in the form of shrubs. However, restoration of the damage on peat swamp forests is always accompanied by a very distinctive environmental response. This response improves the damaged environment according to the potential of the remaining land and other influencing factors.

According to [32]-[37], species diversity can be used to measure community stability, namely the ability of a community to keep itself stable even though there are disturbances to its components. Species diversity shows the level of stability at a growth level, either the seedling, sapling, poles, and tree levels. So that from the amount of the Diversity Index will be compared between the growth level, a higher value will indicate higher stability, so it can be said, in this study, the secondary swamp forest type is more stable in its community than the scrub swamp forest type.

\section{Species Evenness Index (E)}

The calculation of the evenness index (E) on the land cover type of secondary swamp forest and the type of swamp scrub land cover in the area of the Hampangen Educational Forest Nature Laboratory was calculated using the Ludwig and Reynolds formula. The Species Evenness Index (E) at various growth levels is shown in Figure 4.

Figure 4, The number of evenness index species will have a high value if the species diversity index is high and the number of species is large. Conversely, if the Species Diversity Index is low and the number of species is low, then the Evenness Index will be small [22].

The results showed that the Evenness Index (E) in the land cover type of secondary swamp forest and swamp scrub was classified as high with a range of values of $0,753-0,849$. It is stated that if the value of E (Evenness Index) approaches the value of 1 (one), then the evenness is high [15]. This is also supported by [38], [39], which states that if the species evenness index value $\mathrm{E}>0,6$, then the evenness of species is classified as high.

The species evenness index in the Hampangen Educational Forest Nature Laboratory area can be classified into high species evenness. The secondary swamp forest type has an E 'value which is higher than swamp scrub forest. This means that secondary swamp forest has a more evenly distributed species of individuals than swamp scrub. This is possible because there are many shrubs or lianas in the land cover type of swamp shrubs, which cause very high competitiveness between woody plants and shrubs or lianas.

The evenness index shows the degree of evenness of individual abundance between each species. If each type has the same number of individuals, then the community has the maximum evenness value. Conversely, if the evenness value is small, then the community has dominant, sub-dominant, and dominating types, then the community has minimum evenness. The evenness value has a range between $0-1$; if the index value obtained is close to one, it means that the distribution is more evenly distributed. The graph above shows that the secondary swamp forest has an even distribution (0.784-0.834). That is, there are no species that dominate the area. The number of individuals in each species is almost varied and relatively the same.

In contrast to swamp scrublands, the evenness of species was lower $(0.753-0,809)$. This is presumably due to the dominance of certain species at various growth levels, namely the acacia. This species is quite dominant compared to other types in swampy scrubland. That is, there are no species that dominates the area; the number of individuals in each species is almost varied and relatively the same. According [40], the evenness index that higher from an individual of a growth level indicates the distribution of the individuals. The evenness index value is strongly influenced by the diversity index and the number of species. The evenness index will have a high value if the diversity index of species and the number is high, but if the diversity index is low and the number is small, then the evenness index will be small [22].

\section{Species Richness Index $(R)$}

The species richness index can be used to determine the species richness in a forest area. The Species Richness Index (R) for the land cover type of secondary swamp forest and swamp scrub in the Hampangen Educational Forest Nature Laboratory area was calculated using the Margelaf formula [41], whose results are presented in Figure 5.

Species richness is the number of species (species) in a community. The greater the number of species found, the greater the wealth index. The Margalef richness index divides the number of species by a natural logarithm function, which indicates that the increase in the number of species is inversely proportional to the increase in the number of individuals. This also shows that usually in a community/ecosystem with many species will have a small number of individuals in each of these species. Figure 5 shows the average Species Richness Index at various growth rates as indicated by the results of the study, which states that the land cover type of secondary swamp forest is classified as high Species Richness, namely in the range of 5.448 - 5,759, only at the level of trees that are categorized as moderate. On the other hand, the average 
species richness index in the swamp scrub land cover type is classified as low in the range of values 2,382-2,752, only at the pole growth rate which is categorized as moderate. This is presumably due to the dominance of pioneer plants, which are plants that are able to adapt to the environment, can survive disturbances and their growth period is very fast so that the growth level of saplings and piles has high species richness.

According to [42], species richness is the number of species in a community, the more species found, the greater the wealth index. The Margelaf richness index divides the number of species by a natural function which indicates that the increase in the number of species is inversely proportional to the increase in the number of individuals.

\section{E. Species Similarity Index (IS)}

The Species Similarity Index is used to determine the level of species similarity between several plants, between sample units or between several communities that are compared based on the composition and structure of the community. Therefore the size of the similarity index illustrates the level of similarity in the species composition and structure of the two communities or plants and the sampling unit being compared [43], [44]. The results of the calculation of the Similarity Index are presented in Figure 6.

Figure 6, shows the largest species similarity index in the two land cover types is at the pole growth level, namely amounted to $50.91 \%$, and the lowest growth level is at the seedling level, namely equal to $38.10 \%$. All plant species at the seedling, sapling, and tree level had a species similarity index value of less than $50 \%$, and growth at the pole level had an average greater than $50 \%$. [23] stated that the level of species composition similarity is said to be low if it has a species similarity index of less than $<50 \%$ and vice versa, so it can be said that the Species Similarity Index of the two types of land cover is low. [22] stated that the higher the Species Similarity Index value, the higher the level of species similarity between the two communities being compared. It can also be interpreted that the higher the species Similarity Index value, the less the different species composition will be and vice versa. The lower the Species Similarity Index, then the more different species composition will be. The results of the calculation of this species similarity index are shown in the results of the research inventory, which states that the number of individuals ( $\mathrm{N} / \mathrm{ha}$ ) in the land cover type of secondary swamp forest at each growth rate is more than the type of swamp scrub land cover, as well as the number of species in secondary swamp forest. More than that of swamp scrubland cover.

\section{CONCLUSION}

From the results of this study, it can be concluded that there are 52 types of plants found in all types of research areas - a total of 42 species in secondary swamp forest and 26 species in scrublands. Overall, the species with the highest IVI in secondary swamp forest were Meranti $(52,646 \%)$, the lowest IVI was Nyatoh $(17,078)$, while the highest IVI was Acacia (98,314\%) and the lowest was Gerunggang (34,316\%). The Diversity Index of plant species in the study area on both land types was classified as moderate, namely 1,871 - 2,968.
The evenness index value (E) of plants in the land cover type of secondary swamp forest and swamp scrub was classified as high, namely in the range of $0.753-0.849$. The Species Richness Index $(\mathrm{R})$ value of the secondary swamp forest land cover type is classified as high, whereas the swamp scrub land cover type is classified as low, while the average species similarity index in the two land cover types is low. The index of plant species diversity included in the medium category on the two types of land in the study location shows that the Hampangen Educational Forest area has sufficient tree productivity levels, fairly balanced ecosystem conditions, and moderate ecological pressure.

Further research is needed on other types of land cover in the Hampangen Educational Forest Nature Laboratory area in order to find out the dynamics of growth as a reference model for management and supervision of the Hampangen Educational Forest Nature Laboratory area, which includes the species diversity and the composition of the plant. Land rehabilitation efforts in the educational forest area of Hampangen need to be carried out by planting activities together with species enrichment, especially for peat swamp forest plant species. This is in addition to enriching the diversity of endemic plant species in the area as well as suppressing the dominance of exotic plant growth, which is starting to grow in the Nature Laboratory of the Hampangen Educational Forest.

\section{ACKNOWLEDGMENT}

The author's gratitude to the Dean of the Faculty of Agriculture, University of Palangkaraya and the Department of Forestry who has facilitated the implementation of the research. The author also thanks and appreciates the Head of the Hampangen Educational Forest Laboratory and the communities around the area who have helped a lot in carrying out research, especially in data collection in the field.

\section{REFERENCES}

[1] N. Koonkhunthod, K. Sakurai, and S. Tanaka, "Composition and diversity of woody regeneration in a 37-year-old teak (Tectona grandis L.) plantation in Northern Thailand," Forest Ecology and Management, vol. 247, no. 1-3, pp. 246-254, 2007.

[2] J. Aubad, P. Aragón, M. Á. Olalla-Tárraga, and M. Á. Rodríguez, "Illegal logging, landscape structure and the variation of tree species richness across North Andean forest remnants," Forest Ecology and Management, vol. 255, no. 5-6, pp. 1892-1899, 2008.

[3] E. Pohnan, H. Ompusunggu, and C. Webb, "Does tree planting change minds? Assessing the use of community participation in reforestation to address illegal logging in West Kalimantan," Tropical Conservation Science, 
vol. 8, no. 1, pp. 45-57, 2015.

[4] T. C. Khai, N. Mizoue, T. Kajisa, T. Ota, and S. Yoshida, "Stand structure, composition and illegal logging in selectively logged production forests of Myanmar: Comparison of two compartments subject to different cutting frequency," Global ecology and conservation, vol. 7, pp. 132-140, 2016.

[5] A. L. Sinclair et al., "Effects of distance from canal and degradation history on peat bulk density in a degraded tropical peatland," Science of The Total Environment, vol. 699, p. 134199, 2020.

[6] W. B. Miles, "The invisible commodity: Local experiences with forest carbon offsetting in Indonesia," Environment and Planning E: Nature and Space, p. 2514848620905235, 2020.

[7] O. Onrizal and M. Maulana, "Analyses of land cover change of Singkil Swamp Wildlife Reserve in the last 20 years," 2020, vol. 1542, no. 1, p. 012063.

[8] T. Nikonovas, A. Spessa, S. H. Doerr, G. D. Clay, and S. Mezbahuddin, "Near-complete loss of fire-resistant primary tropical forest cover in Sumatra and Kalimantan," Communications Earth \& Environment, vol. 1, no. 1, pp. 1-8, 2020.

[9] L. E. Cole, K. J. Willis, and S. A. Bhagwat, "The future of Southeast Asia's tropical peatlands: local and global perspectives," Anthropocene, p. 100292, 2021.

[10] M. Alam, T. Nath, M. Dahalan, S. Halim, and N. Rengasamy, "Decentralization of forest governance in Peninsular Malaysia: The case of peatland swamp forest in North Selangor, Malaysia," Natural Resource Governance in Asia, pp. 13-26, 2021.

[11] M. L. Morrison, Wildlife restoration: techniques for habitat analysis and animal monitoring, vol. 1. Island Press, 2013.

[12] C. Burlakoti and S. B. Karmacharya, "Quantitative analysis of macrophytes of Beeshazar Tal, Chitwan, Nepal," Himalayan Journal of Sciences, vol. 2, no. 3, pp. 37-41, 2004.

[13] B. Niroula and K. Singh, "Seasonal variation in Importance Value Index (IVI), Diversity Indices and Biomass of aquatic macrophytes at Biratnagar and adjoining areas, eastern
Nepal," Nepalese Journal of Biosciences, vol. 1, pp. 1-7, 2011.

[14] I. Dharmawan, "Evaluasi dinamika cadangan karbon tetap pada hutan gambut primer dan bekas terbakar di Hampangen dan Kalampangan, Kalimantan Tengah," Disertasi). Bogor: IPB, 2012.

[15] A. Soegianto, "Ekologi kuantitatif," Usaha Nasional. Surabaya, vol. 1, pp. 12-13, 1994.

[16] B. H. Saharjo and G. Wibisana, "Persepsi Masyarakat Dalam Upaya Pengendalian Kebakaran Hutan Di Taman Nasional Gunung Ciremai Community Role to the Forest Fire Control in Mount Ciremai National Park," Jurnal Silvikultur Tropika, vol. 8, no. 2, pp. 141-146, 2017.

[17] S. Wicaksono, "Analisa faktor-faktor yang mempengaruhi pemilihan moda transportasi penduduk kerja di Kecamatan Sukmajaya Depok menuju tempat kerja dengan menggunakan metode analytic hierarchy process," 2012.

[18] S. S. Tjitrosoedirjo, "Notes on the profile of Indonesian invasive alien plant species," Biotropia-The Southeast Asian Journal of Tropical Biology, vol. 14, no. 1, pp. 62-68, 2007.

[19] S. Sutedjo and W. Warsudi, "Menakar sifat invasif spesies Akasia mangium (Acacia mangium Willd.) di hutan penelitian dan pendidikan Bukit Soeharto," ULIN: Jurnal Hutan Tropis, vol. 1, no. 1, 2017.

[20] S. Susanti, "Komposisi jenis dan struktur tegakan regenerasi alami di Hutan Pendidikan Gunung walat, Sukabumi [Skripsi]," Bogor: Institut Pertanian Bogor, 2014.

[21] R. Mohfar, "Struktur tegakan dan sebaran jenis ramin dan meranti di hutan rawa gambut (Studi Kasus PT. Diamond Raya Timber dan PT Riau Andalan Pulp and Paper, Provinsi Riau)[skripsi]," Bogor: Fakultas Kehutanan, Institut Pertanian Bogor, 2012.

[22] E. Odum, "Dasar-dasar ekologi umum. Diterjemahkan oleh T. Samingan," Gadjah Mada University Press. Yogyakarta. hlm, vol. 574, pp. 14-27, 1993.

[23] M. Mawazin and A. Subiakto, "Keanekaragaman dan komposisi jenis permudaan alam hutan rawa gambut bekas tebangan di Riau (species diversity and 
composition of logged over peat swamp forest in Riau)," Indonesian Forest Rehabilitation Journal, vol. 1, no. 1, pp. 59-73, 2013.

[24] A. Bhadra and S. Pattanayak, "Dominance is more justified than Abundance to calculate Importance Value Index (IVI) of plant species," Asian Journal of Science and Technology, vol. 8, no. 2, pp. 4304-4326, 2017.

[25] M. Tauseef, F. Ihsan, W. Nazir, and J. Farooq, "Weed Flora and importance value index (IVI) of the weeds in cotton crop fields in the region of Khanewal, Pakistan.," Pakistan Journal of Weed Science Research, vol. 18, no. 3, 2012.

[26] B. B. Lamont, S. Downes, and J. E. Fox, "Importance-value curves and diversity indices applied to a species-rich heathland in Western Australia," Nature, vol. 265, no. 5593, pp. 438-441, 1977.

[27] R. B. Blair, "Land use and avian species diversity along an urban gradient," Ecological applications, vol. 6, no. 2, pp. 506-519, 1996.

[28] J. D. Satler, K. K. Bernhard, J. O. Stireman III, C. A. Machado, D. D. Houston, and J. D. Nason, "Community structure and undescribed species diversity in nonpollinating fig wasps associated with the strangler fig Ficus petiolaris," Insect Systematics and Diversity, vol. 4, no. 2, p. 3, 2020.

[29] N.-F. Wan et al., "Global synthesis of effects of plant species diversity on trophic groups and interactions," Nature plants, vol. 6, no. 5, pp. 503-510, 2020.

[30] E. Martin and B. Winarno, "Peran parapihak dalam pemanfaatan lahan gambut; studi kasus di Kabupaten Ogan Komering Ilir, Sumatera Selatan," Jurnal Analisis Kebijakan Kehutanan, vol. 7, no. 2, pp. 81-95, 2010.

[31] R. M. Sukarna, "Kajian Bentang Lahan Ekologi Floristik Hutan Rawa Gambut Berbasis Citra Penginderaan Jauh Di Sub DAS Sebangau Provinsi Kalimantan Tengah Study of Landscape Ecology Floristic on Peat Swamp Forest Based on Remote Sensing Imagery at Sebangau Sub Catchment Area Central Kalimantan," Jurnal Hutan Tropis, vol. 2, no. 1, pp. 52-59, 2014.

[32] A. Bratawinata, "Ekologi Hutan Hujan Tropis dan Metoda Analisis Hutan," Samarinda: Fakultas Kehutanan Universitas Mulawarman, 2001.

[33] E. Valencia et al., "Synchrony matters more than species richness in plant community stability at a global scale," Proceedings of the National Academy of Sciences, vol. 117, no. 39, pp. 24345-24351, 2020.

[34] B. Wilsey, "Restoration in the face of changing climate: importance of persistence, priority effects, and species diversity," Restoration Ecology, 2020.

[35] T. Lamy, C. Koenigs, S. J. Holbrook, R. J. Miller, A. C. Stier, and D. C. Reed, "Foundation species promote community stability by increasing diversity in a giant kelp forest," Ecology, vol. 101, no. 5, p. e02987, 2020.

[36] C. Ratzke, J. Barrere, and J. Gore, "Strength of species interactions determines biodiversity and stability in microbial communities," Nature ecology \& evolution, vol. 4, no. 3, pp. 376-383, 2020.

[37] C. Hutchison, Loss of community stability as a coherent ecological impact of a changing climate. McGill University (Canada), 2020.

[38] R. Wang et al., "Influence of species richness, evenness, and composition on optical diversity: A simulation study," Remote Sensing of Environment, vol. 211, pp. 218228, 2018.

[39] B. F. Tracy and M. A. Sanderson, "Forage productivity, species evenness and weed invasion in pasture communities," Agriculture, ecosystems \& environment, vol. 102, no. 2, pp. 175-183, 2004.

[40] S. Fontana, M. K. Thomas, M. Moldoveanu, P. Spaak, and F. Pomati, "Individual-level trait diversity predicts phytoplankton community properties better than species richness or evenness," The ISME journal, vol. 12, no. 2, pp. 356-366, 2018.

[41] N. Rao, V. Durve, and V. Shrikhande, "Concept of planktonic species diversity in small water bodies-a case study of lake Rangasagar (Udaipur: Rajasthan)," Acta hydrochimica et hydrobiologica, vol. 16, no. 5, pp. 517-524, 1988.

[42] L. Ismaini, M. Lailati, and S. D. Rustandi, "Analisis komposisi dan keanekaragaman 
tumbuhan di Gunung Dempo, Sumatera Selatan," 2015, vol. 1, no. 6, p. 1398.

[43] A. Chao, R. L. Chazdon, R. K. Colwell, and T. Shen, "A new statistical approach for assessing similarity of species composition with incidence and abundance data," Ecology letters, vol. 8, no. 2, pp. 148-159, 2005.

[44] M. Hejda, P. Pyšek, and V. Jarošík, "Impact of invasive plants on the species richness, diversity and composition of invaded communities," Journal of ecology, vol. 97, no. 3, pp. 393-403, 2009.
Creative Commons Attribution License 4.0 (Attribution 4.0 International,CM3 BY 4.0)

This article is published under the terms of the Creative Commons Attribution License 4.0

https://creativecommons.org/licenses/by/4.0/deed.e $\underline{\mathrm{n} U S}$ 
Table.1 Highest IVI at Each Growth Level in 2 (two) Land Cover Types

\begin{tabular}{|c|c|c|c|c|c|c|}
\hline \multirow{3}{*}{ Growth level } & \multicolumn{6}{|c|}{ Land Cover Type } \\
\hline & \multicolumn{3}{|c|}{ Secondary Swamp Forest } & \multicolumn{3}{|c|}{ Swamp Shrub } \\
\hline & No & Species Name & IVI (\%) & No & Species Name & IVI $(\%)$ \\
\hline \multirow{3}{*}{ Seedling } & 1 & Jambu-jambu & 33,874 & 1 & Akasia & 63,369 \\
\hline & 2 & Nyatoh & 31,546 & 2 & Tumih & 38,575 \\
\hline & 3 & Meranti & 24,953 & 3 & Gerunggang & 34,216 \\
\hline \multirow{3}{*}{ Sapling } & 1 & Jambu-Jambu & 26,662 & 1 & Akasia & 50,460 \\
\hline & 2 & Meranti & 20,989 & 2 & Tumih & 42,432 \\
\hline & 3 & Nyatoh & 17,078 & 3 & Tutup kabali & 36,117 \\
\hline \multirow{3}{*}{ Pole } & 1 & Meranti & 52,646 & 1 & Akasia & 75,882 \\
\hline & 2 & Jambu-jambu & 40,572 & 2 & Tumih & 50,920 \\
\hline & 3 & Mahang & 36,166 & 3 & Tutup kabali & 47,314 \\
\hline \multirow{3}{*}{ Tree } & 1 & Meranti & 48,633 & 1 & Akasia & 98,314 \\
\hline & 2 & Mahang & 43,393 & 2 & Tumih & 51,847 \\
\hline & 3 & Jambu-jambu & 42,075 & 3 & Gerunggang & 41,823 \\
\hline
\end{tabular}

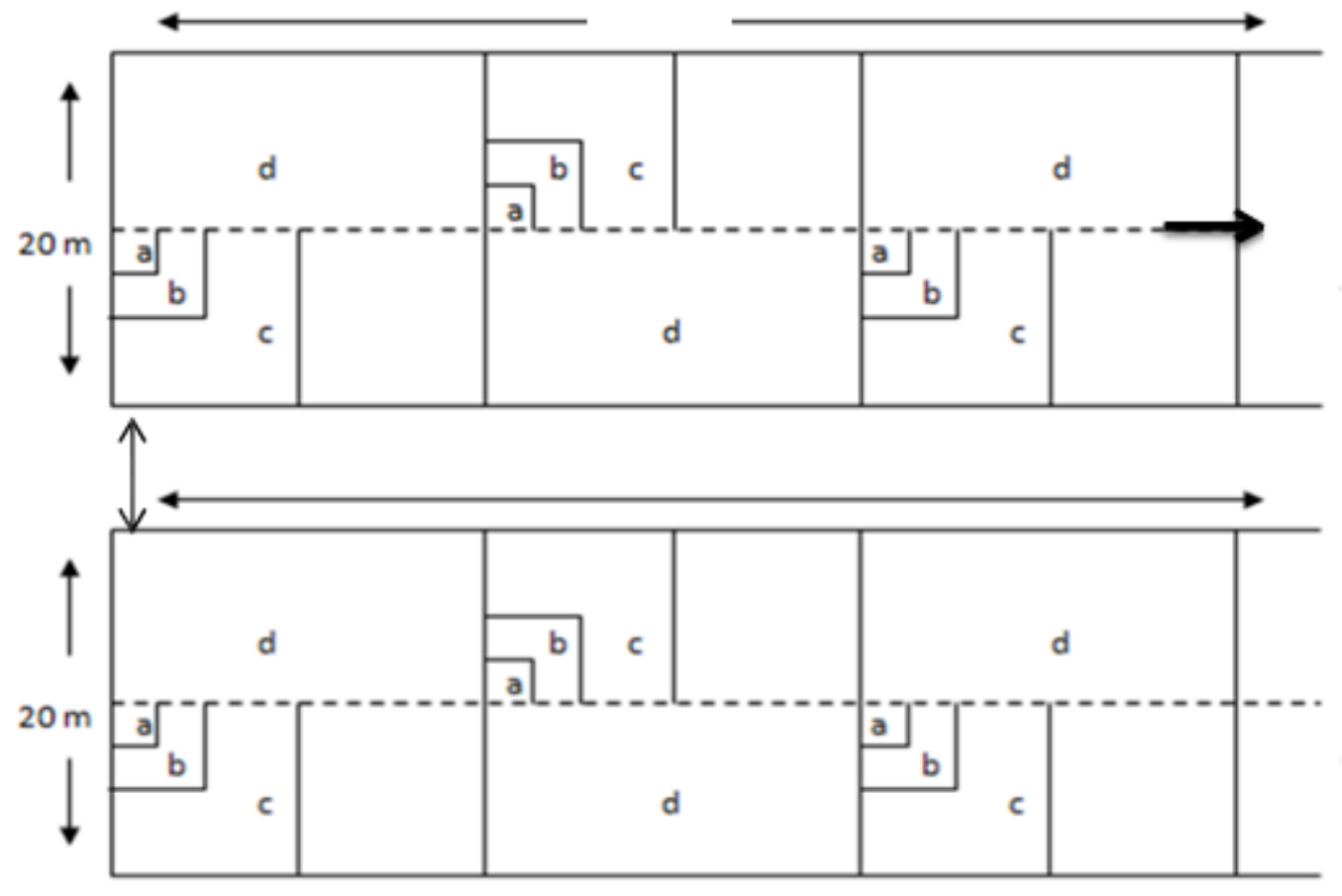

Figure 1. Observation Path Design 


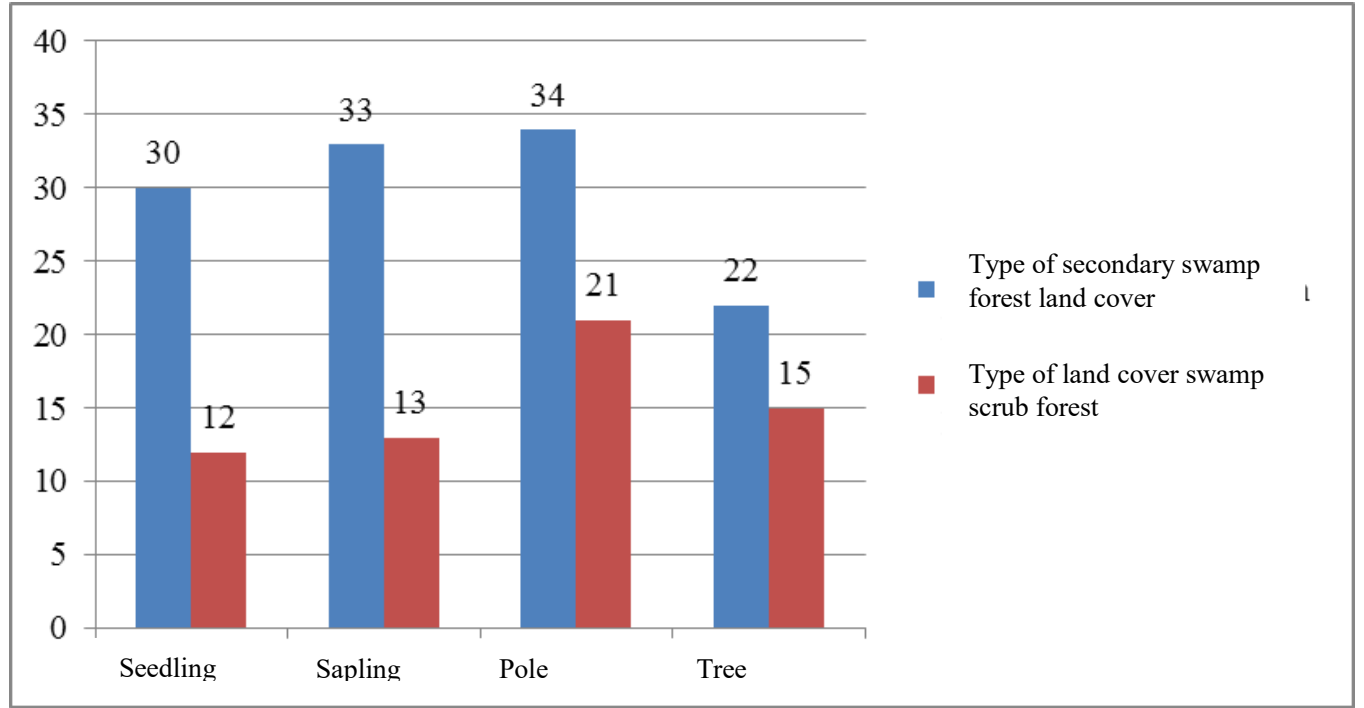

Figure 2. Number of Plant Types in Each Land Cover Type

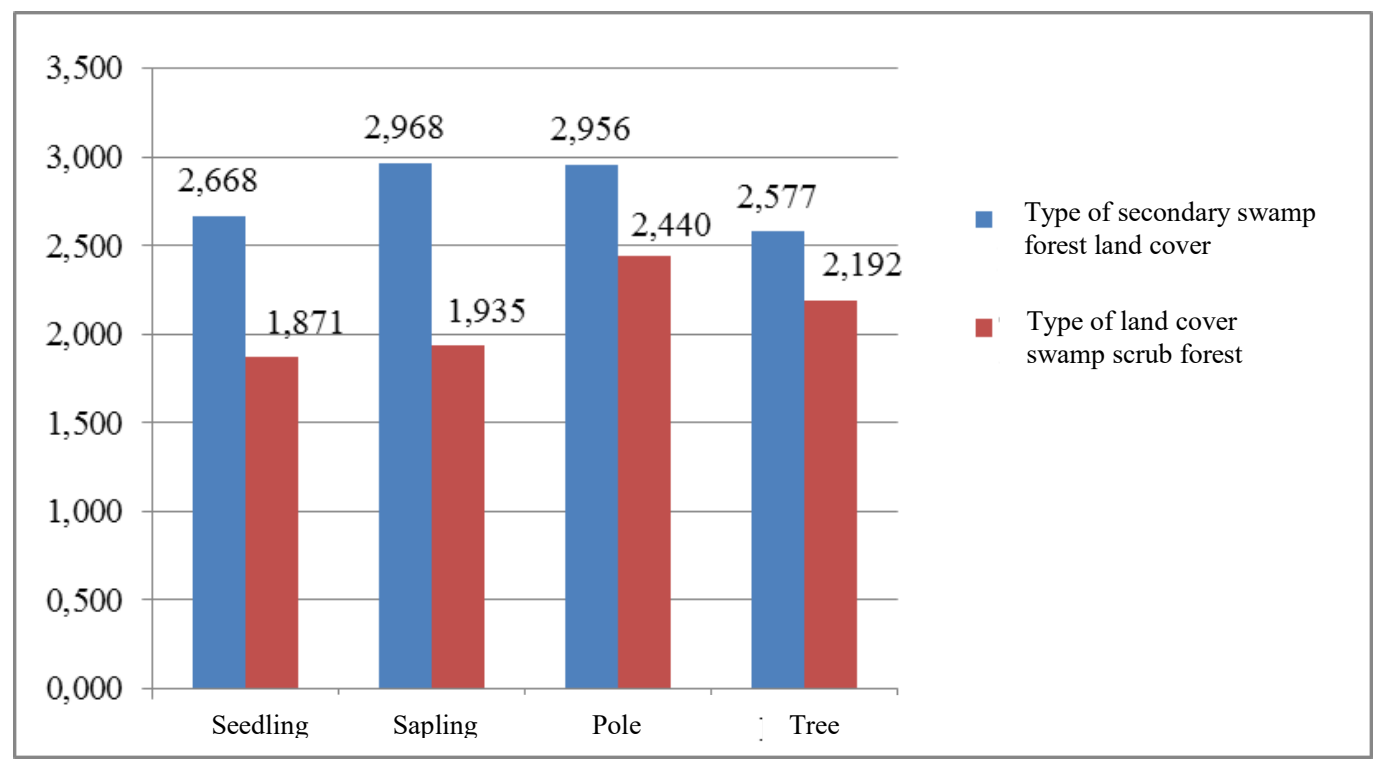

Figure 3. Diversity Index in Each Land Cover Type 


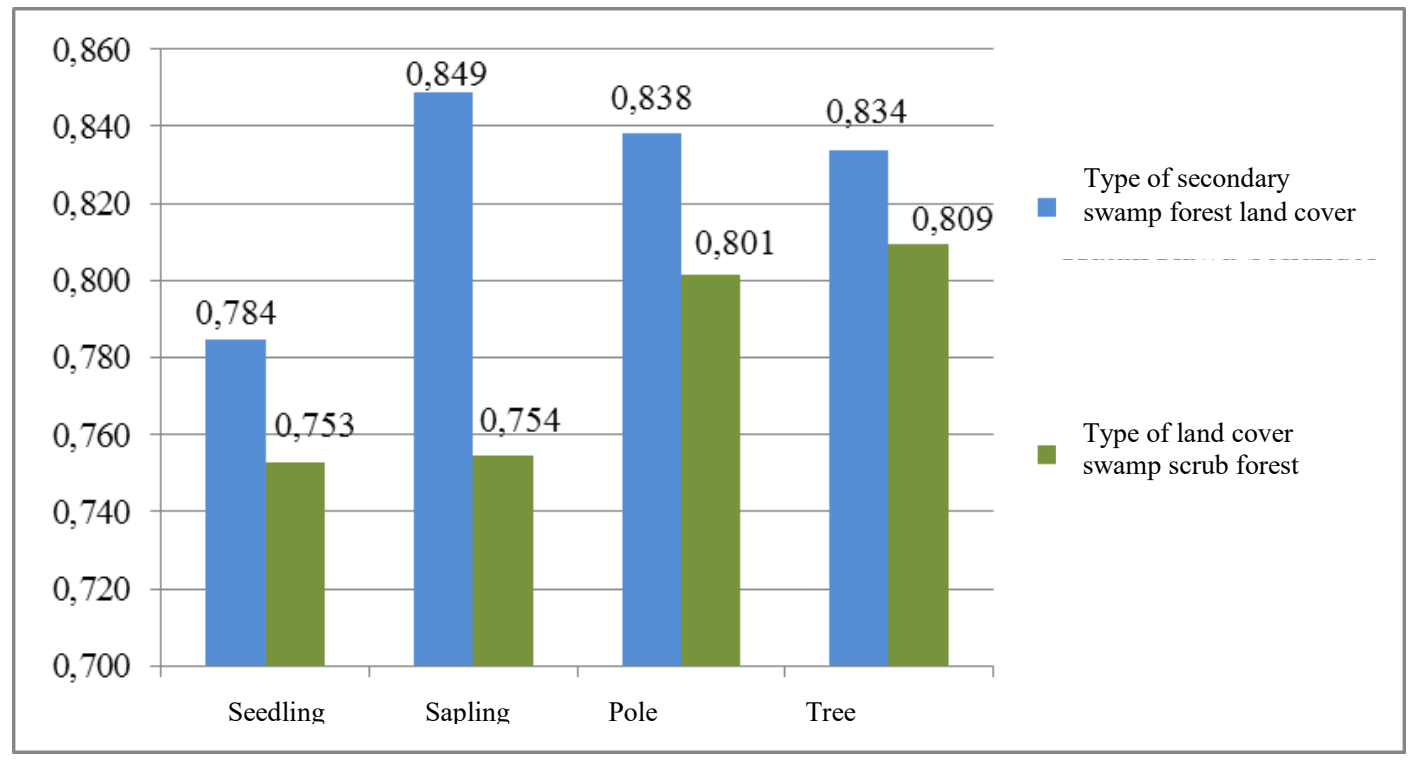

Figure 4. Species Evenness Index for Each Land Cover Type

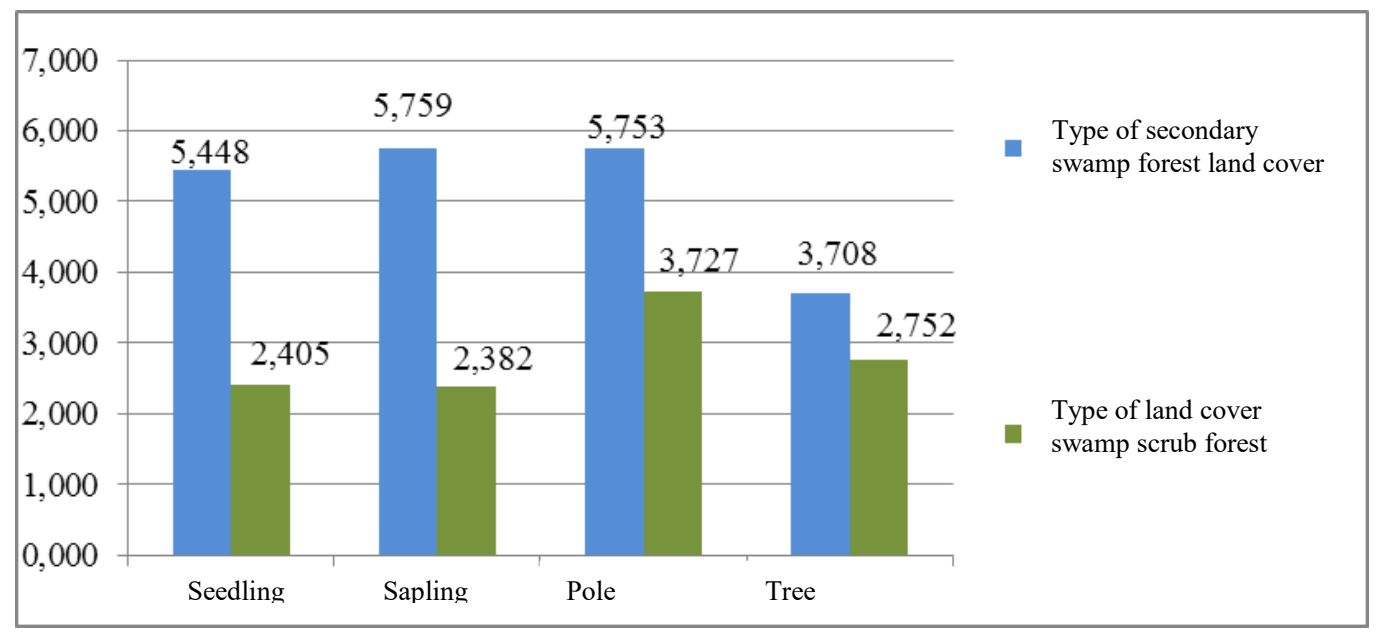

Figure 5. Species Richness Index for each type of land cover 


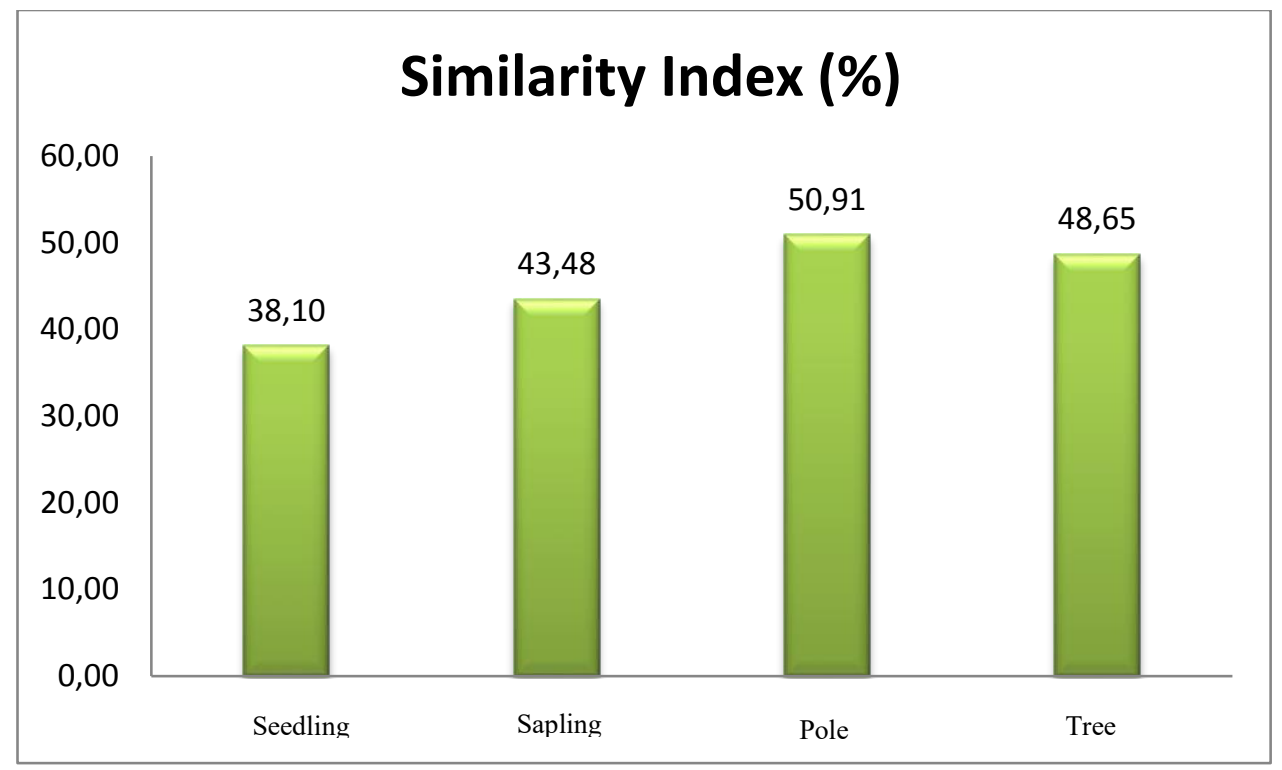

Figure 6. Species Similarity Index for each type of land cover 